\title{
Інтраопераційна характеристика пацієнтів з ішемічною мітральною недостатністю
}

\author{
Руденко С. А., Руденко А. В., Трембовецька О. М., Гогаєва О. К., \\ Лазоришинець В.В.
}

ДУ «Національний інститут серцево-судинної хірургії імені М. М. Амосова НАМН України» (Київ)

\begin{abstract}
Проблема хірургічного лікування ішемічної мітральної недостатності (IMH) актуальна і на сучасному етапі розвитку кардіохірургії. Дискутуються питання показань до різних методSв корекції, удосконалюються методики. Раніше всі операції виконувалися за клапанозамісною методикою, а в останні роки почали диференційовано підходити до вибору методики хірургічної корекції мітральної недостатності ішемічного генезу. Матеріал дослідження склали 142 пацієнти. Хворі були розділені на дві групи залежно від хірургічної тактики лікування. В першу групу ( $\mathrm{n}=93)$ ввійшли хворі, яким було виконано пластичні втручання на клапанах. Хворим другої групи $(\mathrm{n}=49)$ виконувалося протезування мітрального клапана. Тривалість оклюзії аорти досить значно відрізнялася в обох групах. У першій групі вона становила $98,8 \pm 29,2$ хв., тоді як у другій дорівнювала 115,8 $\pm 33,2$ хв., що можна пояснити більшим об'ємом втручання при протезуванні мітрального клапана, оскільки іноді протезуванню передували спроби виконання пластичної операції. Важливим і основним принципом лікування IMH була повна реваскуляризація міокарда. Кількість дистальних анастомозів була зумовлена кількістю уражень ВА і варіювала від одного до шести. ПМШГ $(83,1 \%)$ шунтувалася частіше, ніж усі інші артерії, за винятком ПВА. ПВА шунтували майже з тією ж частотою, що і ПМШГ ЛВА, - у 85,2\% (121). У 108 (76,1\%) пацієнтів методом вибору корекції мітральної недостатності була та чи інша методика пластики мітрального клапана. Однак при ревізії та вивченні результатів в інтраопераційний період у 15 (13,9\%) пацієнтів виконання клапанозберігаючої операції визнано незадовільним. У цих випадках вирішено було виконати протезування мітрального клапана штучним протезом. Отже, із усіх 49 протезувань мітрального клапана штучним протезом тільки 34 (69,4\%) пацієнтам було вирішено виконувати операцію за даним методом із самого початку, а для $15(30,6 \%)$ хворих протезування клапана стало методом вибору після неуспішної клапанозберігаючої корекції мітральної недостатності.
\end{abstract}

Ключові слова: ішемічна мітральна недостатність, ішемічна хвороба серия.

Проблема хірургічного лікування ішемічної мітральної недостатності актуальна і на сучасному етапі розвитку кардіохірургії. Раніше всі операції виконувалися за клапанозамісною методикою, а в останні роки почали диференційовано підходити до вибору методики хірургічної корекції мітральної недостатності ішемічного генезу [1]. Основними показниками, за яким вирішували, згідно з якою методикою проводити корекцію мітральної недостатності, були наявність органічних уражень підклапанного апарату та можливість виконання успішної пластики мітрального клапана.

Мета роботи - проаналізувати інтраопераційний період у хворих на мітральну недостатність ішемічного генезу.

Матеріали та методи дослідження. В період з 2012 по 2014 роки в НICCX імені М. М. Амосова НАМН України було виконано 142 операції з приводу ішемічної мітральної недостатності. Хворі були розділені на дві групи залежно від хірургічної тактики лікування. До першої групи ввійшли 93 (65,5\%) хворих, яким бу- ло виконано пластичні втручання на клапанах. Протезування мітрального клапана виконувалось хворим другої групи - у 49 (34,5\%) випадках. Середній вік хворих становив $61,8 \pm 7,4$ років. Серед пацієнтів переважали чоловіки (74,7\%). Діабет в анамнезі діагностувався у 14,8\% хворих, хронічна ниркова недостатність - у 9,9\%. Майже кожен четвертий пацієнт палив (табл. 1).

\section{Таблиця 1}

Доопераційна характеристика хворих

\begin{tabular}{lc} 
Показники & Кількість пацієнтів \\
\hline Вік хворих & $61,8 \pm 7,4$ років \\
\hline Жіноча стать & $36(25,3 \%)$ \\
\hline Гіпертонічна хвороба & $85(59,9 \%)$ \\
\hline Діабет & $21(14,8 \%)$ \\
\hline Паління & $35(24,6 \%)$ \\
\hline Хронічна ниркова недостатність & $14(9,9 \%)$
\end{tabular}




\section{Таблиця 2}

Інтраопераційні характеристики

\begin{tabular}{lcc} 
Показники & $\begin{array}{c}\text { Пластика } \\
\text { МК }\end{array}$ & $\begin{array}{c}\text { Протезування } \\
\text { МК }\end{array}$ \\
\hline Тривалість перфузії & $171,6 \pm 55,8$ & $195,6 \pm 55,8$ \\
\hline Тривалість перетиснення аорти & $98,8 \pm 29,2$ & $115,8 \pm 33,2$ \\
\hline $\begin{array}{l}\text { Середня кількість шунтів на } \\
1 \text { хворого }\end{array}$ & $2,7 \pm 1,5$ & $3,1 \pm 1,5$ \\
& &
\end{tabular}

Результати та обговорення. Всі хірургічні втручання проводились за стандартною методикою через серединну стернотомію в умовах штучного кровообігу та гіпотермії $32-33^{\circ} \mathrm{C}$. Для захисту міокарда використовувалась кристалоїдна кардіоплегія. Порівнюючи загальний час перфузії в обох групах, бачимо, що в другій він набагато довший, ніж у першій $(195,6 \pm 55,8$ та 171,6 $\pm 55,8$ відповідно). Тривалість оклюзії аорти теж досить значно відрізнялася в обох групах. В першій групі вона становила 98,8 $\pm 29,2$ хв., тоді як у другій дорівнювала $115,8 \pm 33,2$ хв. Це можна пояснити більшим об'ємом втручання, що виконували при протезуванні мітрального клапана, оскільки іноді протезуванню передували спроби виконання пластичної операції. Привертає увагу і різниця в кількості дистальних анастомозів в обох групах. Так, при протезуванні клапана в середньому виконувалось $3,1 \pm 1,5$ анастомози, а в групі пластичних методик значно менше $-2,7 \pm 1,5$. Інтраопераційні дані штучного кровообігу в нашому дослідженні відповідають даним провідних іноземних фахівців $[1,2]$.

За нашим протоколом важливим і основним принципом лікування IMH була повна реваскуляризація міокарда, виконана в усіх випадках (табл. 3). Кількість дистальних анастомозів була зумовлена кількістю уражень ВА і варіювала від одного до шести. Шунтування одної вінцевої артерії виконувалось у $14,8 \%$ випадків. Необхідність накладання двох анастомозів із вінцевими артеріями виявилась у 23,2\%. Майже кожному четвертому хворому виконали шунтування трьох вінцевих артерій (26,7\%). У 7,0\% пацієнтів були настільки поширені ураження вінцевих судин, що їм було необхідно шунтувати шість вінцевих артерій.

В обох групах частіше за інші було виконано анастомоз до ПВА (табл. 4). Проте ПМШГ шунтувалася

\section{Таблиця 3}

Розподіл кількості шунтованих артерій за групами

\begin{tabular}{ccccccc} 
& \multicolumn{7}{c}{ Кількість шунтованих артерій } \\
\cline { 2 - 7 } Показники & $\mathbf{1}$ & $\mathbf{2}$ & $\mathbf{3}$ & $\mathbf{4}$ & $\mathbf{5}$ & $\mathbf{6}$ \\
$\mathrm{BA}$ & $\mathbf{B A}$ & $\mathbf{B A}$ & $\mathbf{B A}$ & $\mathbf{B A}$ & BA \\
\hline $\mathrm{N}$ & 21 & 33 & 38 & 26 & 14 & 10 \\
\hline$\%$ & 14,8 & 23,2 & 26,7 & 18,3 & 9,8 & 7,0
\end{tabular}

\section{Таблиця 4}

Частота шунтування артерій

\begin{tabular}{lcc} 
Анастомози до & $\mathbf{N}$ & $\mathbf{\%}$ \\
\hline ПМШГ & 118 & 83,1 \\
\hline ДВ & 50 & 35,2 \\
\hline a. intermedia & 12 & 8,4 \\
\hline ОГ I & 76 & 53,5 \\
\hline ОГ ІІ & 42 & 29,6 \\
\hline ПВА & 121 & 85,2 \\
\hline ГГК & 24 & 16,9
\end{tabular}

частіше, ніж усі інші артерії, за винятком ПВА $(83,1 \%)$ (табл. 3). Анастомози до ДГ виконувалися з меншою частотою $(35,2)$. ОГ І ЛВА частіше шунтували, ніж ОГ II ЛВА (53,5\% проти 29,6\%). ПВА шунтували майже 3 такою ж частотою, як і ПМШГ ЛВА, - у 85,2\% (121).

Аналіз розподілу анастомозів до ГГК ПВА виявив, шо вона була анастомозована вдвічі частіше, ніж а. intermedia (16,9\% та $8,4 \%$ відповідно), а анастомози до a. intermedia виконувалися в чотири рази рідше, ніж до ДВ $(8,4 \%$ проти $35,2 \%)$.

У $108(76,1 \%)$ пацієнтів методом вибору корекції мітральної недостатності були різні методики пластики мітрального клапана. Однак при ревізії та оцінці результатів за допомогою гідропроби у $15(13,9 \%)$ клапанозберігаючих операціях результати визнано незадовільними. В цих випадках вирішено було виконати протезування мітрального клапана штучним протезом, що не вплинуло на безпосередні результати операцій. Отже, із всіх 49 протезувань мітрального клапана штучним протезом тільки $34(69,4 \%)$ пацієнтам було вирішено виконувати операцію за даним методом із самого початку, а для 15 (30,6\%) хворих протезування клапана стало методом вибору після неуспішної клапанозберігаючої корекції мітральної недостатності, що підтверджують й інші дослідники. Частота ускладнень із приводу пластичної корекції мітральної недостатності відповідає середньостатистичній у провідних клініках світу [3, 4].

Висновки. Пластика мітрального клапана є методом вибору хірургічного лікування ішемічної мітральної недостатності. Однак анатомічна складність післяінфарктних уражень мітрального клапана у 13,9\% не дозволила виконати клапанозберігаючу операцію, призвівши до протезування. В групі протезування мітрального клапана діагностували більший об'єм ураження вінцевих артерій, що зумовлювало значне ушкодження клапанних структур та підклапанного апарату.

\section{Література}

1. Acker MA, Parides MK, Perrault LP, et al; CTSN. Mitralvalve repair versus replacement for severe ischemic mitral regurgitation. N Engl J Med 2014; 370 (1); 23-32. 
2. Moonesinghe SR, Harris S, Mythen MG, et al. Survival after postoperative morbidity: a longitudinal observational cohort study. Br J Anaesth 2014;11; 977-984.

3. Goldstein D, Moskowitz AJ, Gelijns AC, et al. Two-year outcomes of surgical treatment of severe ischemic mitral regurgitation. N Engl J Med 2016; 374; 344-353.
4. Kron IL, Hung J, Overbey JR, et al. Predicting recurrent mitral regurgitation after mitral valve repair for severe ischemic mitral regurgitation. J Thorac Cardiovasc Surg 2015;149;752-761.

\title{
Intraoperative characteristic of patients with ischemic mitral insufficiency
}

\author{
Rudenko S. A., Rudenko A. V., Lazoryshynetz V. V., Trembovetskaya E. N., Gogaeva E. K.
}

National M. M. Amosov Institute of Cardiovascular Surgery National Academy of Medical Sciences of Ukraine (Kyiv)

In the past, almost all operations were performed according to the prosthetic technique, and in recent years we have begun to differentiate our approach to the choice of methods for the surgical correction of mitral insufficiency of ischemic genesis. Patients were divided into two groups depending on the surgical treatment tactics. The first group included patients who underwent plastic surgery on the valves. Prosthetic mitral valve was performed in patients of the second group. The duration of aortic occlusion is also quite significantly different in both groups. In the first group, it was $98.8 \pm 29.2 \mathrm{~min}$., whereas in the second $-115.8 \pm 33.2 \mathrm{~min}$. On the one hand, this can be explained by the large amount of work that was performed during mitral valve replacement. It is understood that sometimes prosthetics were preceded by attempts to perform plastic surgery. The number of distal anastomoses was determined by the number of affected coronary arteries. In 108 (76.1\%) patients, mitral valve repair was the method of choice for the correction of mitral insufficiency. However, during the revision and study of the results in the intraoperative period, 15 (13.9\%) performed the valve-preserving operation as not being sufficiently successful. In these cases, it was decided to perform a prosthetic mitral valve. Of all 49 mitral valve prosthetics, only 34 (69.4\%) patients decided to perform an operation using this method from the very beginning. And for $15(30.6 \%)$ patients, valve prosthetics became the method of choice after unsuccessful mitral plasty.

Key words: ischemic mitral insufficiency, ischemic heart disease. 